Review

\title{
A Giant Ostrich from the Lower Pleistocene Nihewan Formation of North China, with a Review of the Fossil Ostriches of China
}

\author{
Eric Buffetaut $1,2, *(\mathbb{D})$ and Delphine Angst ${ }^{3}(\mathbb{D}$ \\ 1 Centre National de la Recherche Scientifique—CNRS (UMR 8538), Laboratoire de Géologie de l’Ecole \\ Normale Supérieure, PSL Research University, 24 rue Lhomond, CEDEX 05, 75231 Paris, France \\ 2 Palaeontological Research and Education Centre, Maha Sarakham University, \\ Maha Sarakham 44150, Thailand \\ 3 School of Earth Sciences, University of Bristol, Life Sciences Building, 24 Tyndall Avenue, \\ Bristol BS8 1TQ, UK; angst.delphine@gmail.com \\ * Correspondence: eric.buffetaut@sfr.fr
}

check for updates

Citation: Buffetaut, E.; Angst, D. A Giant Ostrich from the Lower Pleistocene Nihewan Formation of North China, with a Review of the Fossil Ostriches of China. Diversity 2021, 13, 47. https://doi.org/ $10.3390 / \mathrm{d} 13020047$

Academic Editor: Michael Wink Received: 30 December 2020 Accepted: 22 January 2021 Published: 26 January 2021

Publisher's Note: MDPI stays neutral with regard to jurisdictional claims in published maps and institutional affiliations.

Copyright: (c) 2021 by the authors. Licensee MDPI, Basel, Switzerland. This article is an open access article distributed under the terms and conditions of the Creative Commons Attribution (CC BY) license (https:// creativecommons.org/licenses/by/ $4.0 /)$.

\begin{abstract}
A large incomplete ostrich femur from the Lower Pleistocene of North China, kept at the Muséum National d'Histoire Naturelle (Paris), is described. It was found by Father Emile Licent in 1925 in the Nihewan Formation (dated at about $1.8 \mathrm{Ma}$ ) of Hebei Province. On the basis of the minimum circumference of the shaft, a mass of $300 \mathrm{~kg}$, twice that of a modern ostrich, was obtained. The bone is remarkably robust, more so than the femur of the more recent, Late Pleistocene, Struthio anderssoni from China, and resembles in that regard Pachystruthio Kretzoi, 1954, a genus known from the Lower Pleistocene of Hungary, Georgia and the Crimea, to which the Nihewan specimen is referred, as Pachystruthio indet. This find testifies to the wide geographical distribution of very massive ostriches in the Early Pleistocene of Eurasia. The giant ostrich from Nihewan was contemporaneous with the early hominins who inhabited that region in the Early Pleistocene.
\end{abstract}

Keywords: ostrich; China; Nihewan; Pleistocene; femur

\section{Introduction}

The Lower Pleistocene fossiliferous beds of the Nihewan Basin (Figure 1) in northern Hebei Province (North China) have been known for their vertebrate remains since the 1920s. More recently, abundant evidence of early human occupation has also come to light ([1], and references therein). The fossil mammals from the various formations of the Nihewan Basin have attracted considerable attention, starting with the pioneering paper by Teilhard de Chardin and Piveteau [2]. However, although bird bones have been mentioned, few of them have been described in detail, with the notable exception of a metatarsus belonging to a crow (Corvus) [3].

Here we describe an ostrich femur, collected in the 1920s and kept in the paleontology collection of the Muséum National d'Histoire Naturelle (Paris, France). Although this bone is poorly preserved, a body mass estimate based on its circumference shows that it belonged to a giant ostrich, significantly larger than the living Struthio camelus. It provides new evidence of the wide geographical distribution of giant ostriches in the Early Pleistocene of Eurasia.

A note on spelling: in this paper we have used the modern pīnyīn spelling for place names. In the 1920s, a different transliteration was used by paleontologists working in China: "Nihowan" instead of Nihewan, "Sangkan Ho" instead of Sanggan He, etc.

Institutional abbreviations: MNHN: Muséum National d'Histoire Naturelle, Paris, France. IVPP: Institute of Vertebrate Paleontology and Paleoanthropology, Beijing, China. 


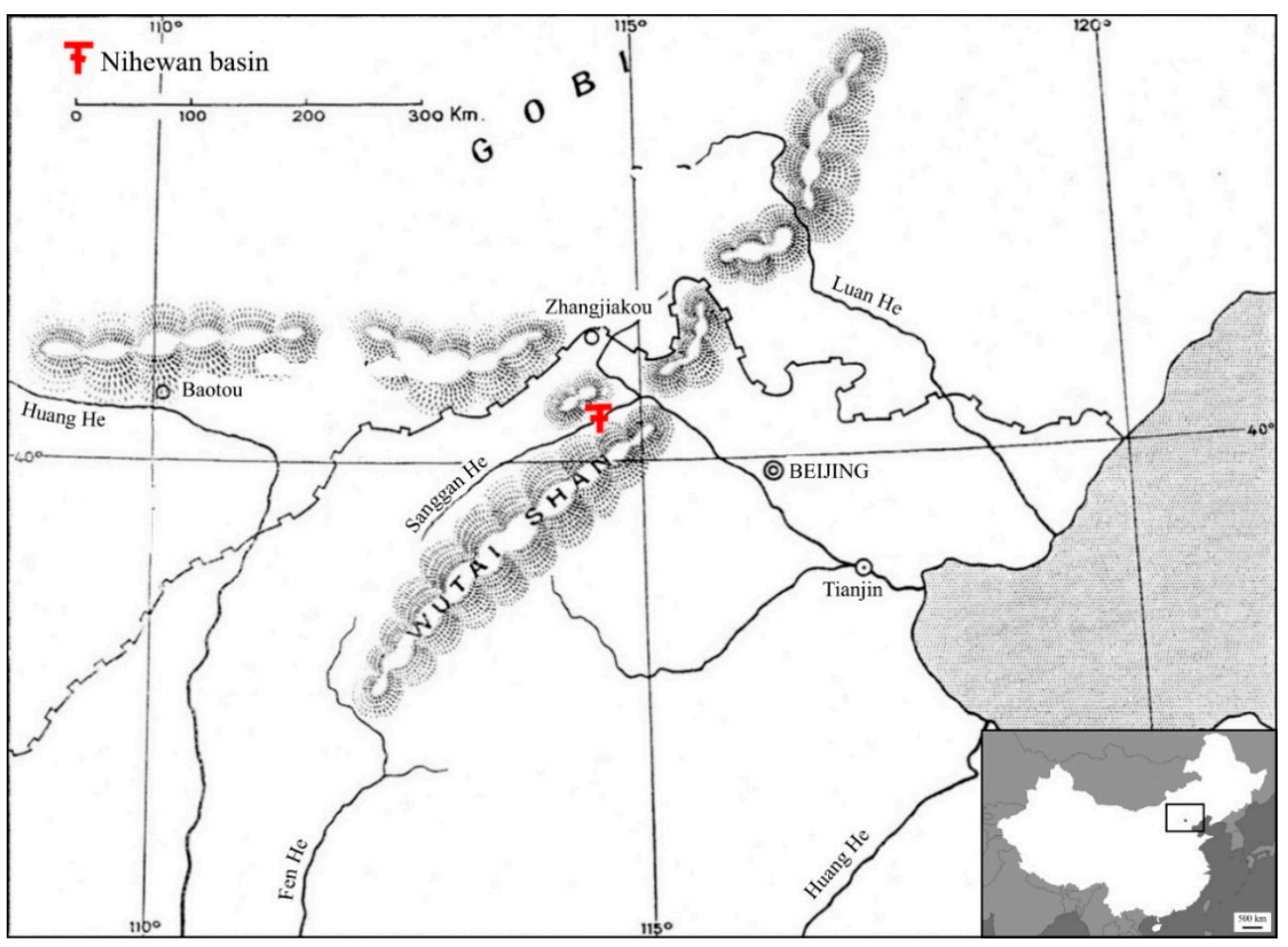

Figure 1. Map of part of northern China showing location of the Nihewan Basin, WNW of Beijing, with general location in China (small map at lower right corner). Modified after Teilhard de Chardin and Piveteau [2].

\section{Discovery and Geological Setting of the Specimen}

Following discoveries of fossil bones by Father Vincent, a missionary based in Nihewan village (some $150 \mathrm{~km}$ NW of Beijing; Figure 1), in 1920 [4-6], the area was visited independently but almost simultaneously by the British geomorphologist George B. Barbour [7] and the French Jesuit and naturalist Emile Licent in 1924 [4]. Abundant vertebrate (mainly mammal) remains were subsequently collected from the Nihewan Basin in the course of field trips led by Licent in 1925 and Licent and Teilhard de Chardin in 1926 [6].

The first mention of an ostrich bone from the Nihewan Basin is in a section on the antiquity of the ostrich in eastern Asia in the monograph by Boule et al. [8] on the Paleolithic in China. The authors note (p. 92) that Licent has found in the "Sanmenian" [Lower Pleistocene] beds of the Sanggan He (the river which flows through the Nihewan Basin) an ostrich femur more than $340 \mathrm{~mm}$ in length, indicating a bird larger than the living ostrich. This brief mention seems to have attracted little attention, although it was noted by Lowe [9] and Lambrecht [10]. Later, in their study of the Nihewan mammals, Teilhard de Chardin and Piveteau [2] briefly mentioned in a footnote (p. 126) the few bird remains in their collection, viz. a humerus of a large vulture and an ostrich femur. These two bones are kept together at the MNHN, the ostrich bone bearing number NIH008. A second number, 1927-13, refers to a catalog entry briefly listing a collection of vertebrate fossils from Nihewan brought back from his second mission to China by Teilhard de Chardin on 20 November 1927. The words "Struthio" and "Femur" are written in pencil on the bone. There is therefore no doubt that the femur described below is that mentioned by Teilhard de Chardin and Piveteau in 1930. Whether it is the same bone as that mentioned by Boule et al. [8] is not so clear, because specimen MNHN-NIH008, in its present condition, is $247 \mathrm{~mm}$ in length, while the length provided by Boule et al. [8] is more than $340 \mathrm{~mm}$. This may suggest that two distinct ostrich femora were found in the Nihewan beds in the 1920s and that one of them may have remained in China while the other was sent to Paris. However, no ostrich femur is currently kept at the Hoang Ho Pai Ho Museum in Tianjin, where Licent's collections are kept, and there is no evidence that such a bone was part of 
the fossils that were transferred from the Hoang Ho Pai Ho Museum to Beijing in 1940 by Teilhard de Chardin and Leroy (see Leroy [11] about this transfer) and are now kept at the IVPP in Beijing. We therefore suppose that MNHN-NIH008 is indeed the bone mentioned by Boule et al. [8], which is no longer as complete as it was when Licent found it (probably during his 1925 collecting trip, when Teilhard de Chardin was not with him, since Licent alone is credited with the discovery), having lost a good part of the distal end.

Many vertebrate localities are currently known in the Nihewan Basin, in formations of different geological ages (see Cai et al. [12], for a recent review), and the exact place where the ostrich femur was found is unclear, all the more so given that Licent does not mention this find in his publications about his collecting trips in the Nihewan Basin ([4,13]). However, the early collections made by Licent and Teilhard de Chardin in the region were restricted to a relatively small area around the villages of Nihewan and Xiashagou (see map in Teilhard de Chardin and Piveteau ([2], p. 8). This corresponds to what Cai et al. [12] call the "classic Nihewan fauna" from the middle part of the Nihewan Formation. This fauna is about 1.8 Ma in age, according to Cai et al. [12].

\section{Description}

Specimen MNHN-NIH008 is a right femur (Figure 2) lacking the distal end (at least one-third of the bone seems to be missing) and the proximal articular head (caput femoris). Some craniocaudal compression seems to have occurred. Some areas in the proximal region have been roughly repaired with plaster. The bone is poorly preserved, its cortex being broken into many pieces on the cranial surface, whereas the caudal surface has been less affected, except in its proximal part. At the level of the distal break, it can be seen that the shaft is hollow and filled with brownish clay. Its bony walls are up to $6 \mathrm{~mm}$ in thickness. Cancellous bone can be seen at the proximal end where the cortex is broken. The bony structure of the specimen is thus clearly avian.

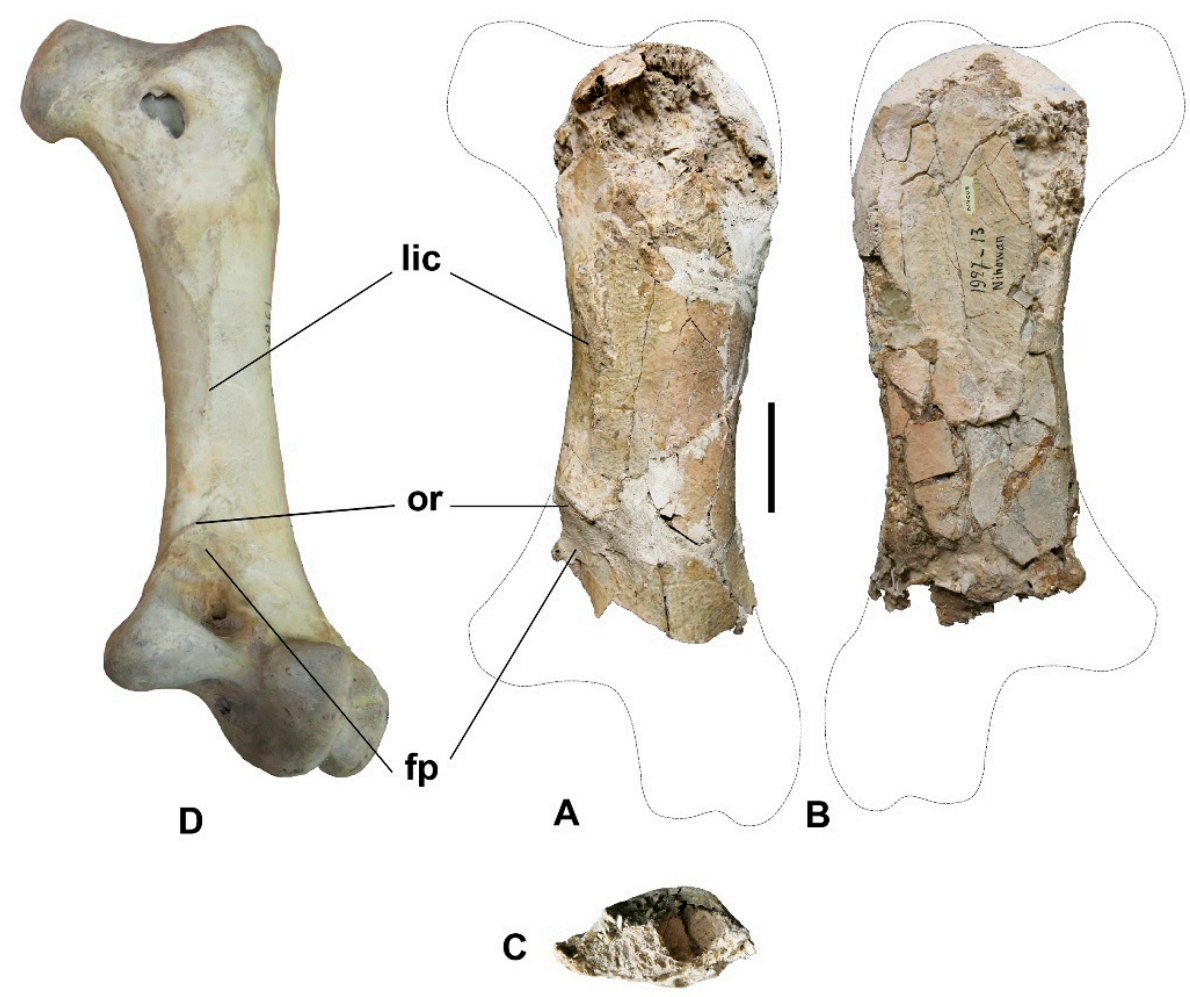

Figure 2. Right femur of giant ostrich (Pachystruthio indet.), MNHN-NIH008, from the Lower Pleistocene of the Nihewan Basin, northern China, in caudal (A), cranial (B) and distal (C) views, compared with a femur of the living ostrich Struthio camelus in caudal view (D). Abbreviations: fp: fossa poplitea; lic: linea intermuscularis caudalis; or: oblique ridge. Scale bar: $50 \mathrm{~mm}$. 
Very little is preserved of the proximal articular area, both the caput femoris and the trochanter femoris being destroyed. The cranial face of the bone is relatively flat and featureless. On the caudal face, a long, well-marked longitudinal ridge, the linea intermuscularis caudalis (Figure 2, lic), is visible in the medial half of the bone. It is broad and strongly rugose in its proximal part and becomes sharper distally. At its distal end, it meets a shorter, oblique ridge that extends mediodistally from the medial margin of the bone. Beyond this oblique ridge, the surface of the bone is somewhat depressed, indicating the beginning of the fossa poplitea (Figure 2, fp). At roughly this level, the width of the shaft begins to increase, but nothing is preserved of the distal articular area.

The minimum width of the bone is $74 \mathrm{~mm}$. Its length as preserved is $247 \mathrm{~mm}$. Considering that at least one-third of the bone is missing distally and that the trochanter femoris is broken, its original length must have been very close to the $340 \mathrm{~mm}$ mentioned by Boule et al. [8].

Although the specimen is very incomplete, the characters that can be observed, in particular the extent and development of the linea intermuscularis caudalis (Figure 2, lic), are in agreement with an attribution to an ostrich, confirming Teilhard de Chardin and Piveteau's identification.

\section{Body Mass Estimate, Comparison with Other Giant Ostriches and Identification}

Using the equation published by Campbell and Marcus [14] [LogM $=2.411 \times \operatorname{LogLCF}$ - 0.065], we used the minimum circumference of the shaft $(\mathrm{LCF}=199 \mathrm{~mm})$ of MNHNNIH008 to estimate the body mass of the Nihewan ostrich. The estimated mass, $300 \mathrm{~kg}$, is twice that of a large male Struthio camelus (Figure 3; Table 1). This Early Pleistocene ostrich was clearly a very large bird, in the mass range of some of the largest known birds, such as the giant moa, Dinornis robustus [15]. This suggests that the Nihewan ostrich was even larger than the giant ostrich from the Late Pleistocene of China, Struthio anderssoni. According to a mass estimate based on the minimum circumference of the shaft of a femur from the Upper Cave at Zhoukoudian (IVPP V6943), S. anderssoni reached a weight of $269 \mathrm{~kg}$, a result in good agreement with estimates based on the dimensions of various Pleistocene eggs from the loess of North China referred to that large ostrich [16]. Morphologically, MNHNNIH008 differs from the Zhoukoudian femur (described by Shaw [17] and Hou [18]) in having a more robust shaft (Figure 4A). A complete femur from Zhoukoudian Upper Cave (present whereabouts unknown) measured by Shaw [17] was $355 \mathrm{~mm}$ in length and $69 \mathrm{~mm}$ in diameter at midlength, which indicates a more slender bone than MNHN-NIH008.

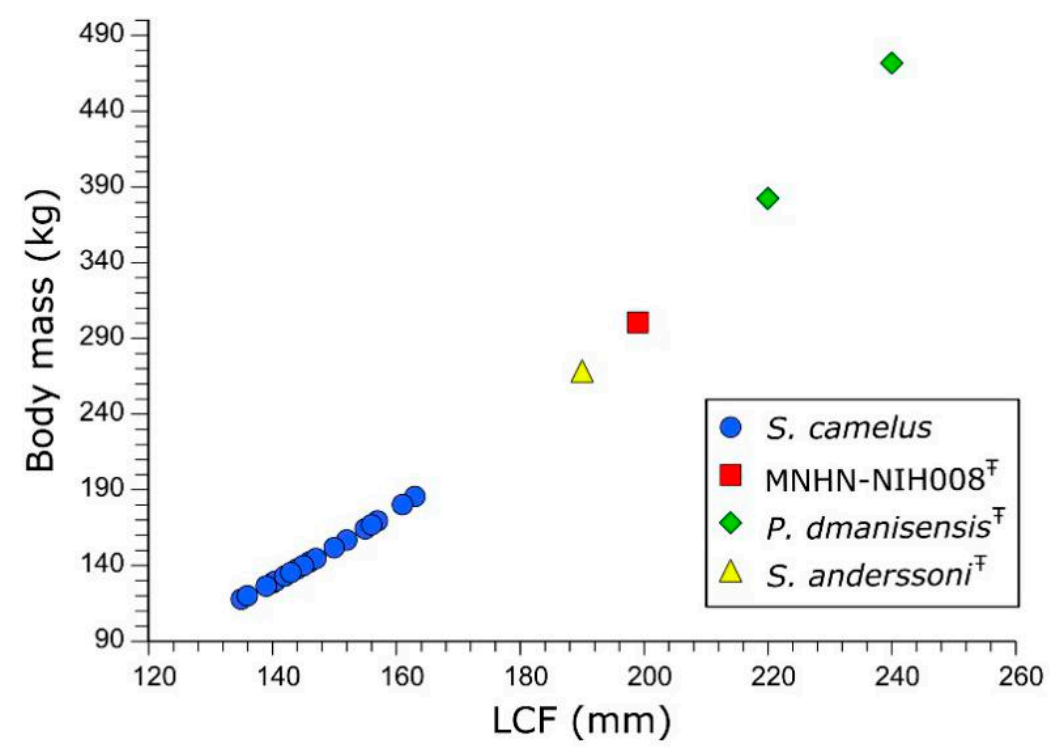

Figure 3. Body mass estimated from the minimum circumference of the shaft (LCF) for several fossil ostriches found in the Pleistocene of Eurasia, compared with the living Struthio camelus. 


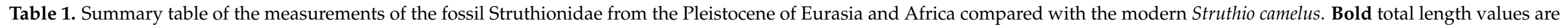
estimated. LCF: minimum circumference of the shaft of the femora.

\begin{tabular}{|c|c|c|c|c|c|c|c|c|c|}
\hline $\begin{array}{l}\text { Specimen } \\
\text { Number }\end{array}$ & Species & Age & Geological Location & $\begin{array}{l}\text { LCF } \\
(\mathrm{mm})\end{array}$ & $\begin{array}{c}\text { Body Mass } \\
\text { Estimated } \\
\quad(\mathrm{kg})\end{array}$ & $\begin{array}{c}\text { Total } \\
\text { Length } \\
(\mathrm{mm})\end{array}$ & $\begin{array}{l}\text { Minimum } \\
\text { Shaft Width } \\
\quad(\mathrm{mm})\end{array}$ & $\begin{array}{c}\text { Stoutness } \\
\text { Index } \\
(\%)\end{array}$ & Source \\
\hline NIH008 & Pachystruthio indet. & Early Pleistocene & Nihewan Formation (China) & 199 & 300 & 340.0 & 74.0 & 21.76 & Boule et al. 1928; this paper \\
\hline D70 & Pachystruthio dmanisensis & Early Pleistocene & Dmanisi (Georgia) & 220 & 382 & 380.0 & 76.0 & 20.00 & $\begin{array}{l}\text { Burchak-Abramovich \& } \\
\text { Vekua 1990; Vekua } 2013\end{array}$ \\
\hline D5768 & Pachystruthio dmanisensis & Early Pleistocene & Dmanisi (Georgia) & 220 & 382 & 385.0 & 76.0 & 19.74 & $\begin{array}{l}\text { Burchak-Abramovich \& } \\
\text { Vekua 1990; Vekua } 2013\end{array}$ \\
\hline PIN 5644/56 & Pachystruthio dmanisensis & Early Pleistocene & Taurida Cave (Crimea) & 240 & 472 & 390.0 & 74.7 & 19.15 & Zelenkov et al. 2019 \\
\hline / & Struthio anderssoni & Late Pleistocene & Zhoukoudian (China) & / & / & 355.0 & 69.0 & 19.44 & Shaw 1937 \\
\hline / & Struthio camelus & Modern & / & 140 & 129 & 301.0 & 38.4 & 12.75 & this paper \\
\hline / & Struthio camelus & Modern & / & 140.5 & 130 & 327.0 & 36.9 & 11.29 & this paper \\
\hline 1888.377 & Struthio camelus & Modern & / & 146 & 142 & 300.0 & 49.0 & 16.33 & this paper \\
\hline 1888.377 & Struthio camelus & Modern & / & 147 & 145 & 300.0 & 50.0 & 16.67 & this paper \\
\hline 1889.171 & Struthio camelus & Modern & / & 144 & 138 & 330.0 & 45.0 & 13.64 & this paper \\
\hline 1889.171 & Struthio camelus & Modern & / & 145 & 140 & 307.0 & 40.0 & 13.03 & this paper \\
\hline 1889.31 & Struthio camelus & Modern & / & 135 & 118 & 310.0 & 49.0 & 15.81 & this paper \\
\hline 1889.31 & Struthio camelus & Modern & / & 136 & 120 & 330.0 & 45.0 & 13.64 & this paper \\
\hline 1922.105 & Struthio camelus & Modern & / & 142 & 133 & 286.0 & 32.0 & 11.19 & this paper \\
\hline 1922.105 & Struthio camelus & Modern & / & 157 & 170 & 320.0 & 43.0 & 13.44 & this paper \\
\hline 1923.2163 & Struthio camelus & Modern & / & 152 & 157 & 320.0 & 42.0 & 13.13 & this paper \\
\hline 1923.2163 & Struthio camelus & Modern & / & 150 & 152 & 315.0 & 46.0 & 14.60 & this paper \\
\hline 1937.114 & Struthio camelus & Modern & / & 139 & 126 & 325.0 & 45.0 & 13.85 & this paper \\
\hline / & Struthio camelus & Modern & Baku & 156 & 167 & 310.0 & 51.0 & 16.45 & $\begin{array}{c}\text { Burchak-Abramovich and } \\
\text { Vekua } 1990\end{array}$ \\
\hline / & Struthio camelus & Modern & Moscow & 143 & 135 & 314.0 & 46.0 & 14.65 & $\begin{array}{c}\text { Burchak-Abramovich and } \\
\text { Vekua } 1990\end{array}$ \\
\hline / & Struthio camelus & Modern & Krakow & 163 & 186 & 325.0 & 51.0 & 15.69 & $\begin{array}{c}\text { Burchak-Abramovich and } \\
\text { Vekua } 1990\end{array}$ \\
\hline / & Struthio camelus & Modern & Krakow & 161 & 180 & 318.0 & 49.0 & 15.41 & $\begin{array}{c}\text { Burchak-Abramovich and } \\
\text { Vekua } 1990\end{array}$ \\
\hline / & Struthio oldawayi & Early Pleistocene & Olduvai Gorge, Tanzania & / & / & 400.0 & 64.0 & 16.00 & Leakey 1967; Vekua 2013 \\
\hline
\end{tabular}


Other Early Pleistocene large ostriches for which the femur is known include Struthio oldawayi Lowe, 1933 from Olduvai Gorge, Tanzania [19]. The femur of S. oldawayi figured by Leakey [20] has a more slender shaft than that of the Nihewan bone (minimum width about $64 \mathrm{~mm}$ ) but is longer (total length about $400 \mathrm{~mm}$ ). Ostrich femora more closely resembling the Nihewan bone are known from the Early Pleistocene of Georgia (Dmanisi [21,22]) and the Crimea (Taurida Cave [23]) (Figures 4 and 5). The giant ostrich from Dmanisi was originally described as Struthio dmanisensis by Burchak-Abramovich and Vekua [21]. More recently, Zelenkov et al. [23] have placed both the ostrich from Dmanisi and that from the Taurida Cave in the genus Pachystruthio Kretzoi, originally erected as a subgenus of Struthio by Kretzoi [24] for a large phalanx and eggshell remains from the Early Pleistocene of Hungary, described as Struthio (Pachystruthio) pannonicus. Femora of P. dmanisensis described by Vekua [22] are ca. $380 \mathrm{~mm}$ and $385 \mathrm{~mm}$ in length, with smallest (mediolateral) shaft widths of $76 \mathrm{~mm}$. The femur of the giant bird from Taurida Cave is ca. $390 \mathrm{~mm}$ in length, with a smallest shaft width of $74.7 \mathrm{~mm}$ [23]. In terms of shaft width, the Nihewan ostrich thus seems more reminiscent of the giant ostriches from Georgia and Crimea than of S. oldawayi.

Burchak-Abramovich and Vekua [22] and Vekua [23] used what they called the stoutness (or massiveness) index, i.e., the minimum shaft width/total length ratio, expressed in percent, to compare the femora of various ostriches (Figure 6; Table 1). In the living Struthio camelus specimens measured by Burchak-Abramovich and Vekua [22], the index ranges from 13.8 to 16.4; it is ca. 16 in Struthio oldawayi and 20.0 in P. dmanisensis, which has an exceptionally massive femur, as noted by Vekua [23]. The stoutness index for the femur from Taurida Cave, calculated on the basis of the measurements provided by Zelenkov et al. [23], is 19.15. Based on the measurements provided by Shaw [17], the stoutness index for the femur of Struthio anderssoni is 19.44. Calculating the stoutness index for MNHN-NIH008 is of course difficult because the bone in its present state is incomplete. If we accept that MNHN-NIH008 is the femur mentioned by Boule et al. [8], which was more than $340 \mathrm{~mm}$ in length, we obtain a stoutness index of 21.76, using 340 $\mathrm{mm}$ as the total length; this is higher than the index for Pachystruthio dmanisensis (Figure 6; Table 1). However, the index calculated for the Nihewan specimen is probably slightly exaggerated because, according to Boule et al. [8], the total length of the bone was more than $340 \mathrm{~mm}$. Nevertheless, it can be assumed that MNHN-NIH008 had a high stoutness index, comparable to that of Pachystruthio dmanisensis, which it resembles in the robustness of the shaft and the development of the linea intermuscularis caudalis (although the latter is in a more central position on the shaft in the specimen from Taurida Cave than in those from Nihewan and Dmanisi). Although a precise identification of MNHN-NIH008 is difficult because of the incompleteness of the specimen, these similarities with the more or less coeval species from Georgia and Crimea are notable and, pending the discovery of more material from the Nihewan Formation, we refer to the specimen as Pachystruthio indet. Although the eastern European localities and Nihewan are some $6000 \mathrm{~km}$ apart (Figure 5), the occurrence of the same taxon of ostrich at both localities cannot be ruled out, because there were considerable similarities between the vertebrate faunas of various parts of Eurasia, from China to western Europe, in the Early Pleistocene, possibly linked to the development of extensive grasslands [25] — an idea already put forward to explain the Pleistocene distribution of the ostrich in Eurasia by Andersson [26]. 


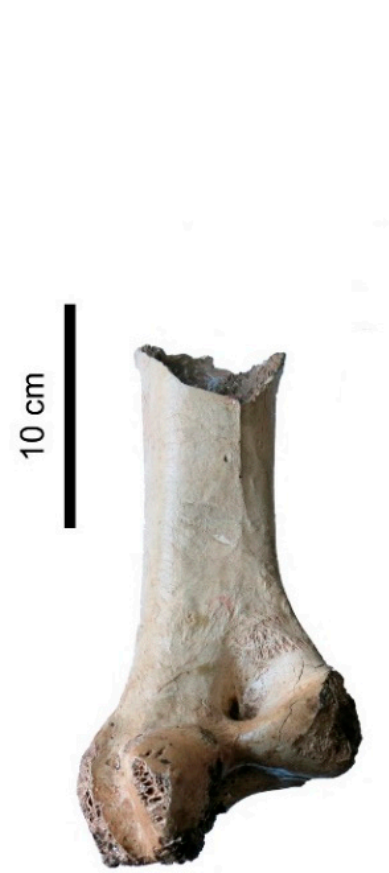

A.

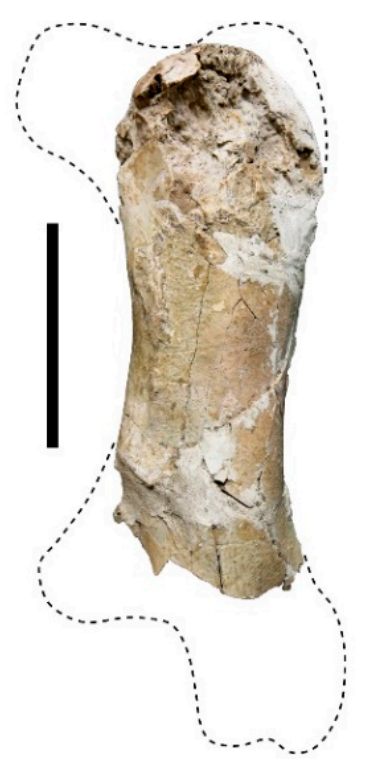

E.1.

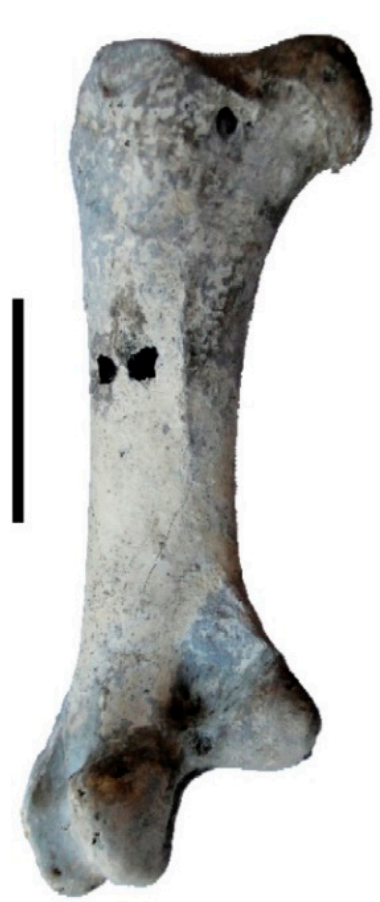

B.

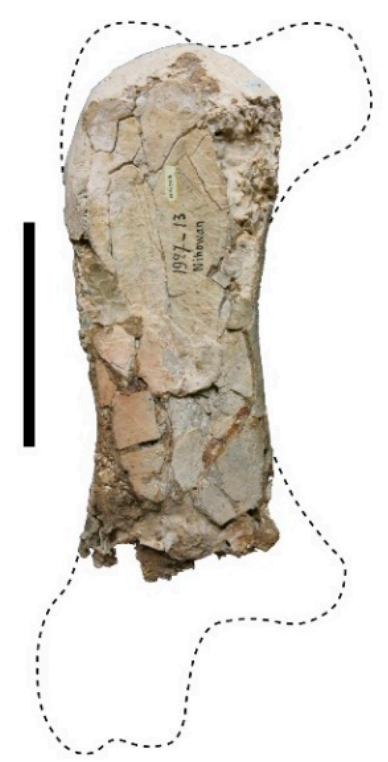

E.2.

C.
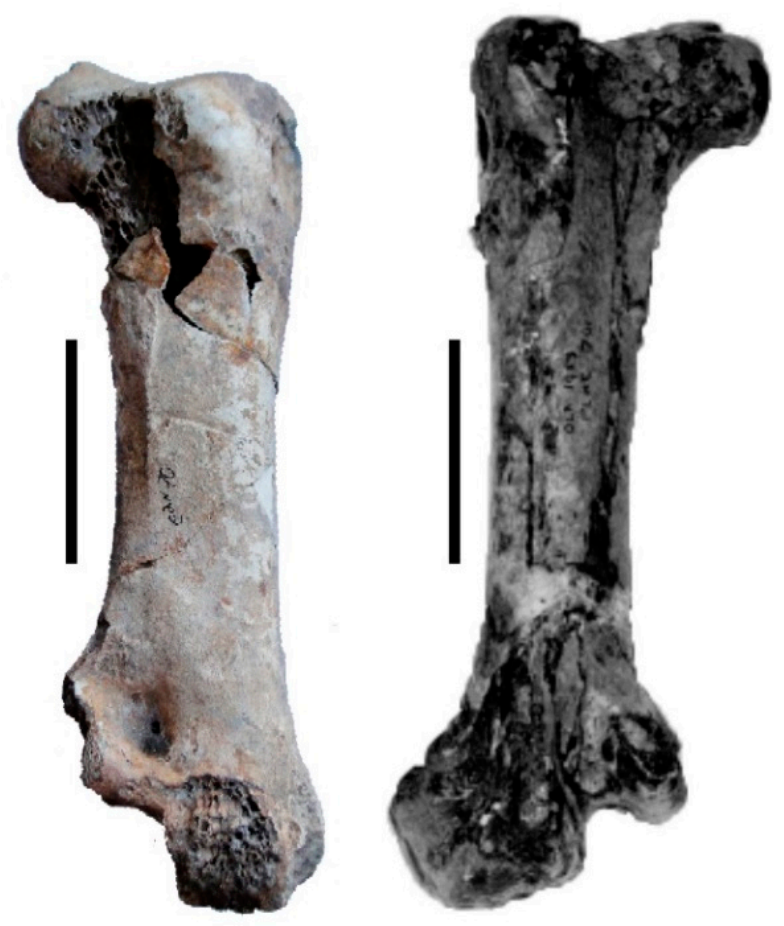

D.

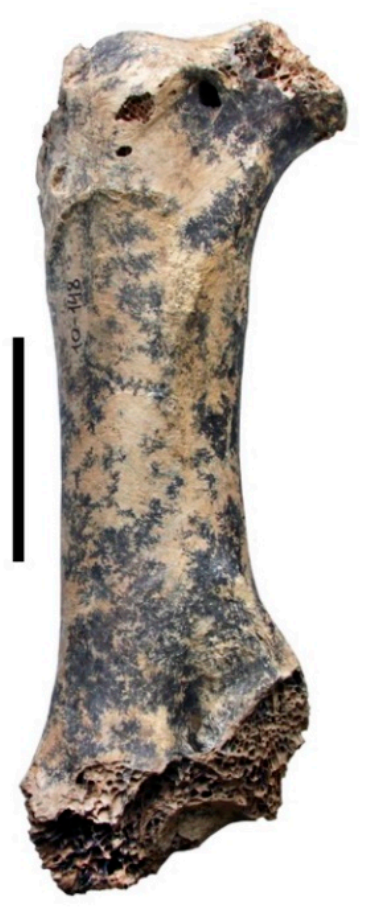

Figure 4. Comparison of the femur MNHN-NIH008 with other femora of Pleistocene ostriches. (A) Femur of Struthio anderssoni, from Zhoukoudian (China), specimen number IVPP V6943, in caudal view. (B) Femur of Pachystruthio cf. dmanisensis), from Dmanisi (Georgia), specimen number D5768, in cranial view (from [22]). (C) Femur of Pachystruthio cf. dmanisensis), from Dmanisi (Georgia), specimen number D70, in caudal view (from [22]). (D) Femur of Struthio oldawayi, from Olduvai (Tanzania), in cranial view (from [20]); E: femur of giant ostrich (Pachystruthio indet.), specimen number MNHN-NIH008, from the Lower Pleistocene of the Nihewan Basin, northern China, in caudal (E.1) and cranial (E.2) views. (F) Femur of Pachystruthio cf. dmanisensis, from Taurida Cave (Crimea), specimen number PIN 5644/56, in caudal view (from [23]). 


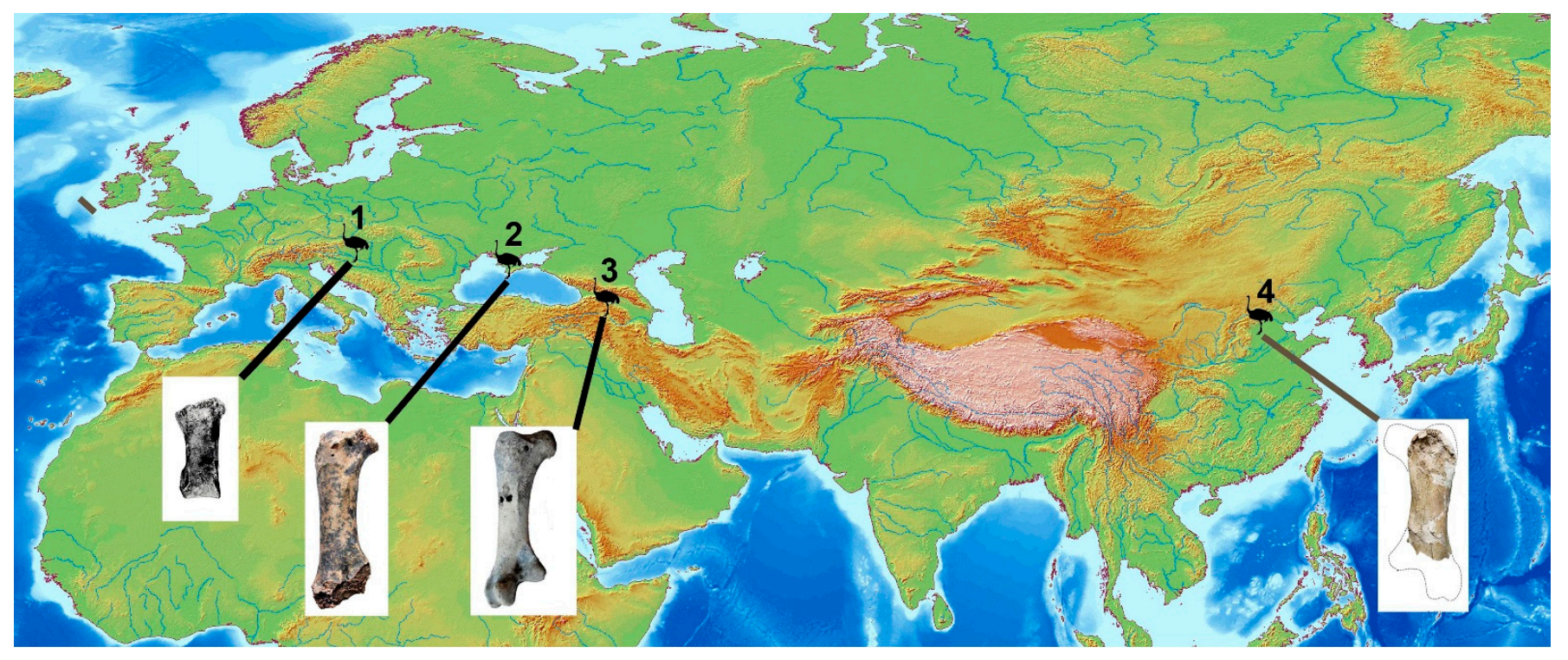

Figure 5. Map showing the distribution of skeletal remains referrable to Pachystruthio in the Lower Pleistocene of Eurasia. 1: Kisláng, Hungary (phalanx, after [24]); 2: Taurida Cave, Crimea (femur, after [23]); 3: Dmanisi, Georgia (femur, after [22]); 4: Nihewan, China (femur, this paper). The bones are not to scale.

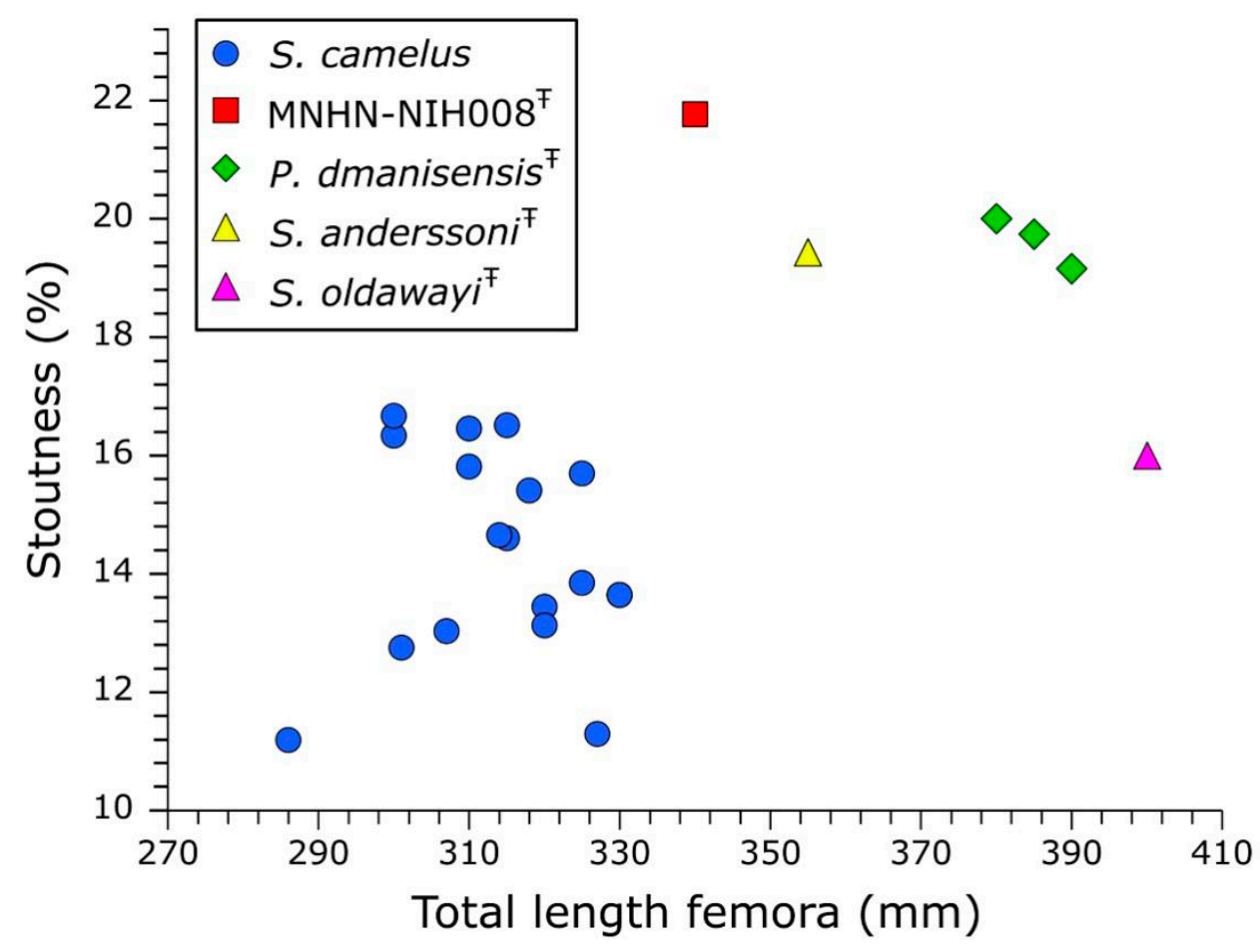

Figure 6. Stoutness (minimum shaft width/total length ratio) vs. total length of the femora of various Pleistocene fossil ostriches, compared with the living Struthio camelus.

\section{A Brief Review of the Fossil Record of Ostriches in China}

The giant ostrich from the Nihewan Formation adds an Early Pleistocene link to a succession of large to very large ostriches known from Neogene and Quaternary formations in China. The earliest record of ostriches or ostrich-like birds from China seems to be eggshell fragments from two Lower Miocene localities in Inner Mongolia [27]. However, Mikhailov and Zelenkov [28] have suggested that the eggshell fragments may have been derived from more recent sediments. This suggestion is based on the fact that the eggshell 
fragments belong to a type which supposedly was not present in Asia at such an early date, and clearly this claim must be checked, possibly by further field observations, before the hypothesis of an erroneous dating is confirmed. The earliest skeletal remains have been referred to two more or less coeval Late Miocene species, Struthio wimani Lowe, 1931 [9] and S. linxiaensis Hou et al., 2005 [29]. The type specimen of Struthio wimani, a pelvis, was found in the so-called Hipparion red clay of the Baode area of NW Shanxi $[9,30]$. These highly fossiliferous deposits were traditionally referred to the Pontian, a stage once placed in the Pliocene, but are now referred to the Late Miocene [31]. Struthio linxiaensis was erected on the basis of a pelvis from the Liushu Formation (Late Miocene) of the Linxia Basin in Gansu Province [29]. Since both taxa appear to be of roughly the same geological age, it may be wondered whether they should really be considered as separate species, a point already made by Mikhailov and Zelenkov [28]. However that may be, both have been described as being larger than the living Struthio camelus. Ostrich eggshell remains from the Late Miocene ("Hipparion fauna") of Shanxi and Gansu, many of them collected by Emile Licent, were reported by Andersson [30]. Lowe [9] referred these Miocene eggshell fragments to Struthio wimani.

Next in age is the Pachystruthio femur from the Lower Pleistocene Nihewan Formation described in the present paper. Eggshell remains have been reported from various anthropic sites in the Nihewan Basin (see below).

The Late Pleistocene species Struthio anderssoni was originally described by Lowe [9] on the basis of large eggs from many localities in the loess of northern China [30]. Many more eggs from the loess referrable to $S$. anderssoni have subsequently been reported (e.g., [32,33]). The name was later applied to skeletal remains (femora) from the Upper Cave at Zhoukoudian [17,18,34,35], for which dates ranging from 35.1 to $33.5 \mathrm{ky}$ are available [36]. Eggshell fragments are known from several of the karstic localities at Zhoukoudian, of various geological ages, some being significantly older than the Upper Cave [32,35,37]. A discussion of the stratigraphic distribution of Struthiolithus eggshells in the loess of China and of the validity of applying the egg-based taxon Struthio anderssoni to skeletal remains is beyond the scope of this paper. It may be mentioned that mass estimates based on eggs referred to Struthio anderssoni and on a femur from the Upper Cave yield very similar results, viz. about $270 \mathrm{~kg}$ [16]. Both the eggs and the few skeletal remains thus indicate an ostrich significantly larger than the living one.

On the basis of C14 dates, Janz et al. [38] have suggested that ostriches survived in north-eastern Asia, including China, until the Holocene. This is in agreement with the suggestion by Kurochkin et al. [39], based on C14 dates from eggshell fragments, that they may have become extinct in the Holocene in Mongolia and Siberia. However, Khatsenovich et al. [40] have urged caution about dates obtained from ostrich eggshell, a material that poses special problems (including different ages for the outside and the inside of the shell) and which in some instances provides ages that are significantly younger than those obtained from bones from the same sites.

The available fossil record thus suggests that the ostrich has been present in China possibly from the Early Miocene to the Late Pleistocene, a time span covering some $20 \mathrm{My}$. Because of the scarcity of skeletal material (as opposed to the abundance of eggshell remains), it is difficult to reconstruct the evolution of ostriches in that part of the world and the relationships between the several species that have been described are unclear. The fact that these fossil ostriches were larger than the living species seems to be well established, and the form from the Nihewan Formation may have been the most massive of them all.

\section{Conclusions: The Giant Ostrich from Nihewan in Its Environment}

Although the presence of ostrich remains among the Early Pleistocene vertebrate assemblages of the Nihewan Basin was recorded as early as 1928, they have received little attention. Struthio is mentioned in various recent papers about the Nihewan Basin [1,41-45], but often no details are given about the nature of the material, an exception being the paper by Pei et al. [46], which lists eggshells and a coracoid fragment from the Feiliang site. In this 
context, the ostrich is sometimes considered as an environmental indicator. Dennell [44] considers the presence of the ostrich at the Majuangou III site as in agreement with a warm, moist climate, but also lists Struthio dmanisensis at Dmanisi as a steppe indicator. Pei et al. [46] list the ostrich, together with equids, as suggesting large open temperate grasslands, although other evidence (cervids) indicates that forest environments were also present. However, the ecology of the giant Nihewan ostrich may not have been completely similar to that of modern ostriches, which are clearly adapted to open environments. As noted by Vekua [22], the very robustly built femur of Pachystruthio dmanisensis differs from the more slender one of other large Pleistocene ostriches such as S. oldawayi, and may indicate a bird less well adapted to rapid running. Similarly, Zelenkov et al. [23] suppose that Pachystruthio may not have been as good a runner as modern ostriches because of its great body mass. The same probably applies to the very robust Nihewan ostrich. Only the discovery of more complete material will allow a more accurate assessment of the locomotion of these giant ostriches. More generally, the scantiness of the available material makes it difficult to reconstruct the general proportions of these birds and to draw conclusions about their paleobiology. It should be noted that the widespread occurrence of ostrich eggshell fragments (complete eggs being much less common) in the loess of China $[8,30]$, which was deposited under a cold climate during glacial episodes, shows that the presence of ostrich remains cannot be used as evidence for a warm climate.

Largely on the basis of eggshell microstructure and ornamentation, Mikhailov and Zelenkov [46] have proposed a reconstruction of ostrich evolutionary history that is rather complex and will not be discussed here in detail. Suffice it to say that their hypothesis of a Late Pliocene/Early Pleistocene dispersal of giant ostriches belonging to the genus Pachystruthio, from eastern Europe to Central Asia, seems convincing. The occurrence of a giant ostrich referrable to Pachystruthio in the Lower Pleistocene beds of the Nihewan Basin indicates that this dispersal reached much farther eastward than previously realized. The easternmost occurrences of Pachystruthio mentioned by Mikhailov and Zelenkov [28] were finds of Late Pliocene/earliest Pleistocene eggshell remains from eastern Kazakhstan. The Nihewan Basin is located roughly $3000 \mathrm{~km}$ farther east, and the occurrence there of Pachystruthio shows that this giant ostrich in fact inhabited a very large part of central and north-eastern Eurasia in the Early Pleistocene. This in agreement with the idea of ostrich dispersal along the Eurasian steppes, all the way to North China, already put forward by Andersson in 1929 [26].

Zelenkov et al. [23] have suggested that the very large size of Pachystruthio may have been an adaptation to low-nutrition food linked to increased aridity, a hypothesis already put forward by Murray and Vickers-Riche [47] to explain the increasingly large size of Australian dromornithids. This is a possible explanation, but it should be remarked that in China Pachystruthio lived in an environment that was not especially arid (see above). Moreover, the later Struthio anderssoni, although large, was smaller than Pachystruthio despite the fact that it apparently lived under a more arid climate (under which loess was deposited). Moreover, the living ostrich Struthio camelus, which is significantly smaller than Pachystruthio, lives (or used to live) in arid environments such as the margins of the Sahara or the Syrian desert. One could also invoke Bergmann's rule, which states that within a zoological group forms living at higher latitudes under colder climates tend to be larger than those from warmer climates at lower latitudes. However, it can hardly be used to explain the large size of Eurasian ostriches, and especially Pachystruthio, since very large ostriches, such as Struthio oldawayi, are also known from the Pleistocene of tropical Africa.

A final point worth noting is that, like at Dmanisi, Taurida Cave and Olduvai, giant ostriches cohabited with early humans in the Nihewan Basin. Their remains are sometimes found at anthropic sites, such as Goudi [43] and Feiliang [46]. Although there is factual evidence of Paleolithic humans at least butchering ostriches [48], whether the early hominins of the Nihewan Basin hunted the giant ostrich is uncertain: a bird twice the weight of the living ostrich cannot have been an easy prey-although eggshell collecting may have been less hazardous. 
Author Contributions: Both E.B. and D.A. conceived and carried out the study. All authors have read and agreed to the published version of the manuscript.

Funding: This research received no external funding.

Data Availability Statement: Data is contained within the article.

Acknowledgments: We are grateful to Christine Argot and Vincent Pernègre at the Muséum National d'Histoire Naturelle (Paris) for locating the femur from Nihewan and making it available for study. Access to the ostrich femur from Zhoukoudian at the IVPP was made possible by Zhou Zhonghe and useful information about Chinese collections was provided by Deng Tao (IVPP, Beijing) and the staff of the Hoang Ho Pai Ho Museum (Tianjin), especially Zhang Xiaoxiao.

Conflicts of Interest: The authors declare no conflict of interest.

\section{References}

1. Ao, H.; Deng, C.; Dekkers, M.J.; Sun, Y.; Liu, Q.; Zhu, R. New evidence for early presence of hominids in North China. Sci. Rep. 2013, 3, 2403. [CrossRef] [PubMed]

2. Teilhard de Chardin, P.; Piveteau, J. Les mammifères fossiles de Nihowan (Chine). Ann. Paléont. 1930, 19, 1-134.

3. Wang, M.; O'Connor, J.K.; Zhou, Z. The first fossil crow (Corvus sp. indet.) from the Early Pleistocene Nihewan Paleolithic sites in North China. J. Archaeol. Sc. 2013, 40, 1623-1628. [CrossRef]

4. Licent, E. Voyage aux terrasses du Sang Kan Ho, à l'entrée de la plaine de Sining Hien. Pub. Mus. Hoang Ho Pai Ho 1924, 4, 1-14.

5. Barbour, G.B. Preliminary observations in the Kalgan area. Bull. Geol. Soc. China 1924, 3, 153-168. [CrossRef]

6. Barbour, G.B.; Licent, E.; Teilhard de Chardin, P. Geological study of the deposits of the Sangkanho basin. Bull. Geol. Soc. China 1926, 5, 263-278. [CrossRef]

7. Barbour, G.B. The deposits of the Sang Kan Ho valley. Bull. Geol. Soc. China 1925, 4, 53-55. [CrossRef]

8. Boule, M.; Breuil, H.; Licent, E.; Teilhard, P. Le Paléolithique de la Chine. Arch. Inst. Paléont. Hum. 1928, 4, 1-138.

9. Lowe, P.R. Struthious remains from Northern China and Mongolia, with descriptions of Struthio wimani, Struthio anderssoni and Struthio mongolicus, spp. nov. Palaeont. Sin. C 1931, 6, 1-47.

10. Lambrecht, K. Handbuch der Palaeornithologie; Borntrager: Berlin, Germany, 1933.

11. Leroy, P. L'Institut de Géobiologie à Pékin, 1940-1946. Les dernières années du P. Teilhard de Chardin en Chine. L Anthropologie 1965, 69, 360-367.

12. Cai, B.Q.; Zheng, S.H.; Liddicoat, J.; Li, Q. Review of the litho-, bio-, and chronostratigraphy in the Nihewan Basin, Hebei, China. In Fossil Mammals of Asia; Wang, X., Flynn, L.J., Fortelius, M., Eds.; Columbia University Press: New York, NY, USA, 2013; pp. 218-242.

13. Licent, E. Comptes-rendus de onze années (1923-1933) de séjour et d'exploration dans le bassin du Fleuve Jaune, du Pai Ho et des autres tributaires du golfe du Pai Tcheu ly. Pub. Mus. Hoang Ho Pai Ho 1935, 38, 1-1131.

14. Campbell, K.E.; Marcus, L. The relationship of hindlimb bone dimensions to body weight in birds. Nat. Hist. Mus. Los Angeles County Sc. Ser. 1992, 36, 395-412.

15. Angst, D.; Buffetaut, E. Paleobiology of Giant Flightless Birds; Elsevier \& ISTE Press: Oxford/London, UK, 2017.

16. Buffetaut, E.; Angst, D. How large was the giant ostrich of China? Evoluçao 2018, 2, 6-8.

17. Shaw, T.H. Einige Bemerkungen zum Oberschenkelknochen des fossilen Strausses Struthio anderssoni Lowe von Chou Kou Tien in Nord-China. Ornithol. Monatsber. 1937, 45, 201-202.

18. Hou, L. Avian fossils of Pleistocene from Zhoukoudian. Mem. Inst. Vert. Palaeont. Palaeoanthrop. Acad. Sin. 1993, 19, 165-297.

19. Lowe, P.R. On some struthious remains: -1. Description of some pelvic remains of a large fossil ostrich, Struthio oldawayi, sp. n., from the Lower Pleistocene of of Oldaway (Tanganyika Territory); 2. Egg-shell fragments referable to Psammornis and other Struthiones collected by H. St. John Philby in southern Arabia. Ibis 1933, 75, 652-657.

20. Leakey, L.S.B. Olduvai Gorge 1951-1961; Cambridge University Press: Cambridge, UK, 1967; Volume 1.

21. Burchak-Abramovich, N.I.; Vekua, A. The fossil ostrich Struthio dmanisensis sp. n. from the Lower Pleistocene of eastern Georgia. Acta Zool. Cracov. 1990, 33, 121-132.

22. Vekua, A. Giant ostrich in Dmanisi fauna. Bull. Georg. Nat. Acad. Sc. 2013, 7, 143-148.

23. Zelenkov, N.V.; Lavrov, A.V.; Startsev, D.B.; Vislobokova, I.A.; Lopatin, A.V. A giant early Pleistocene bird from eastern Europe: Unexpected component of terrestrial faunas at the time of early Homo arrival. J. Vert. Paleont. 2019. [CrossRef]

24. Kretzoi, M. Ostrich and camel remains from the Central Danube basin. Acta Geologica 1954, 2, $231-242$.

25. Dennell, R.W. The colonization of "Savannahstan": Issues of timing(s) and patterns of dispersal across Asia in the Late Pliocene and Early Pleistocene. In Asian Paleoanthropology: From Africa to China and Beyond; Norton, C.J., Braun, D.R., Eds.; Springer: Dordrecht, The Netherlands, 2010; pp. 7-30.

26. Andersson, J.G. Der Weg über die Steppen. Bull. Mus. Far East. Antiquit. 1929, 1, 143-165.

27. Wang, S.; Hu, Y.; Wang, L. New ratite eggshell material from the Miocene of Inner Mongolia, China. Chinese Birds 2011, 2, 18-26. [CrossRef] 
28. Mikhailov, K.E.; Zelenkov, N. The late Cenozoic history of the ostriches (Aves: Struthionidae), as revealed by fossil eggshell and bone remains. Earth Sc. Rev. 2020, 208, 103270. [CrossRef]

29. Hou, L.; Zhou, Z.; Zhang, F.; Wang, Z. A Miocene ostrich fossil from Gansu Province, northwest China. Chin. Sci. Bull. 2005, 50, 1808-1810. [CrossRef]

30. Andersson, J.G. Essays on the Cenozoic of northern China. Mem. Geol. Surv. China Ser. A 1923, 3, 1-152.

31. Qiu, Z.X.; Qiu, Z.D.; Deng, T.; Li, C.K.; Zhang, Z.Q.; Wang, B.Y.; Wang, X. Neogene Land Mammal Ages/Stages of China. In Fossil Mammals of Asia; Wang, X., Flynn, L.J., Fortelius, M., Eds.; Columbia University Press: New York, NY, USA, 2013; pp. 29-90.

32. Young, C.C. On the new finds of fossil eggs of Struthio anderssoni Lowe in North China, with remarks on the egg remains found in Shansi, Shensi and in Choukoutien. Bull. Geol. Soc. China 1933, 12, 145-152. [CrossRef]

33. Young, C.C.; Sun, A.L. New material of ostrich eggs and its stratigraphic significance. Paleovert. Paleoanthrop. 1960, 2, 115-119. (In Chinese)

34. Shaw, T.H. Preliminary observations on the fossil birds from Chou-Kou-Tien. Bull. Geol. Soc. China 1935, 14, 77-81. [CrossRef]

35. Qi, T. Choukoutienology; Zhejiang University Press and Archaeopress: Hangzhou, China, 2018.

36. Li, F.; Bae, C.J.; Ramsey, C.B.; Chen, F.; Gao, X. Re-dating Zhoukoudian Upper Cave, northern China and its regional significance. J. Hum. Evol. 2018, 121, 170-177. [CrossRef]

37. Zhao, Z.; Yuan, G.; Wang, J.; Zhong, Y. On the amino acid composition and microstructure of fossil ostrich eggshell from Sinanthropus site, Choukoutien. Vert. Palasiat. 1981, 19, 327-337.

38. Janz, L.; Elston, R.G.; Burr, G.S. Dating North Asian surface assemblages with ostrich eggshell: Implications for palaeoecology and extirpation. J. Archaeol. Sci. 2009, 36, 1982-1989. [CrossRef]

39. Kurochkin, E.N.; Kuzmin, Y.V.; Antoshchenko-Olenev, I.V.; Zabelin, V.I.; Krivonogov, S.K.; Nohrina, T.I.; Lbova, L.V.; Burr, G.S.; Cruz, R.J. The timing of ostrich existence in Central Asia: AMS 14C age of eggshells from Mongolia and southernSiberia (a pilot study). Nucl. Instr. Meth. Phys. Res. B 2010, 268, 1091-1093. [CrossRef]

40. Khatsenovich, A.M.; Rybin, E.P.; Gunchinsuren, B.; Bolorbat, T.; Odsuren, D.; Angaragdulguun, G.; Margad-Erdene, G. Human and Struthio asiaticus: One page of Paleolithic art in the eastern part of Central Asia. Izv. Irkutsk. gosudarst. Univers. Ser. Geoarkheol. Etnol. Antrop. 2017, 21, 80-106.

41. Zhu, R.X.; Potts, H.; Xie, F.; Hoffman, K.A.; Deng, C.L.; Shi, C.D.; Pan, Y.X.; Wang, H.Q.; Shi, G.H.; Wu, N.Q. New evidence on the earliest human presence at high northern latitudes in northeast Asia. Nature 2004, 431, 559-562. [CrossRef] [PubMed]

42. Deng, C.; Zhu, R.; Zhang, R.; Ao, H.; Pan, Y. Timing of the Nihewan formation and faunas. Quat. Res. 2008, 69, 77-90. [CrossRef]

43. Shen, C.; Gao, X.; Wei, Q. The earliest hominin occupations in the Nihewan Basin of Northern China: Recent progress in field investigations. In Asian Paleoanthropology: From Africa to China and Beyond; Norton, C.J., Braun, D.R., Eds.; Springer: Dordrecht, The Netherlands, 2010; pp. 169-180.

44. Dennell, R.W. The Nihewan Basin of North China in the Early Pleistocene: Continuous and flourishing, or discontinuous, infrequent and ephemeral occupation? Quat. Intern. 2012, 295, 223-236. [CrossRef]

45. Liu, P.; Deng, C.; Li, S.; Cai, S.; Cheng, H.; Yuan, B.; Wei, Q.; Zhu, R. Magnetostratigraphic dating of the Xiashagou Fauna and implication for sequencing the mammalian faunas in the Nihewan Basin, North China. Palaeogeogr. Palaeoclimat. Palaeoecol. 2012, 315, 75-85. [CrossRef]

46. Pei, S.; Gao, X.; Wang, H.; Kuman, K.; Bae, C.J.; Chen, F.; Guan, Y.; Zhang, Y.; Zhang, X.; Peng, F.; et al. Early Pleistocene archaeological occurrences at the Feiliang site, and the archaeology of human origins in the Nihewan Basin, North China. PLoS ONE 2017, 12, e0187251. [CrossRef]

47. Murray, P.F.; Vickers-Rich, P. Magnificent Mihirungs: The Colossal Flightless Birds of the Australian Dreamtime; Indiana University Press: Bloomington/Indianapolis, IN, USA, 2004.

48. Bonilauri, S.; Boëda, E.; Griggo, C.; Al-Sakhel, H.; Muhesen, S. Un éclat de silex moustérien coincé dans un bassin d'autruche (Struthio camelus) à Umm el Tlel (Syrie centrale). Paléorient 2007, 33, 39-46. [CrossRef] 